Review Article

\title{
Application of QuEChERS for Determining Xenobiotics in Foods of Animal Origin
}

\author{
Coralia V. Garcia and Ahmed Gotah \\ Department of Food Science and Technology, Keimyung University, Daegu 42601, Republic of Korea \\ Correspondence should be addressed to Coralia V. Garcia; cvvgarcia@kmu.ac.kr
}

Received 24 July 2017; Accepted 15 October 2017; Published 24 December 2017

Academic Editor: Bradley B. Schneider

Copyright ( 2017 Coralia V. Garcia and Ahmed Gotah. This is an open access article distributed under the Creative Commons Attribution License, which permits unrestricted use, distribution, and reproduction in any medium, provided the original work is properly cited.

\begin{abstract}
The use of pesticides and veterinary drugs results in the appearance of residues of xenobiotics in foods. Thus, several methods have been developed for monitoring them; however, most are tedious and expensive. By contrast, the QuEChERS (Quick, Easy, Cheap, Effective, Rugged, and Safe) methodology involves a microextraction that yields small samples and has been applied for the analysis of various xenobiotics including pesticides, antibiotics, and mycotoxins. QuEChERS has shown advantages over other techniques including fast sample preparation, reduced needs for reagents and labware, and versatility. This approach allows the simultaneous determination of pesticides with various polarities and volatilities and can be easily modified for the analysis of a wide range of xenobiotics in various matrices including animal products rich in fat. Nevertheless, to attain high recoveries, the extraction, cleanup, and concentration steps have to be optimized according to the target compounds and matrix. Hence, QuEChERS is a promising and environmentally friendly methodology for the high-throughput routine analysis of xenobiotics in animal products. This review focuses on the application of QuEChERS to foods of animal origin and describes recent developments for the optimization of the analysis of veterinary drugs, pesticides, polycyclic aromatic hydrocarbons, and other compounds of concern.
\end{abstract}

\section{Introduction}

The QuEChERS (Quick, Easy, Cheap, Effective, Rugged, and Safe) methodology was reported for the first time in 2003 by Anastassiades and coworkers as an alternative to traditional pesticide analysis [1]. QuEChERS involves a microscale extraction with acetonitrile combined with dispersive solid-phase extraction (d-SPE) using primary secondary amine (PSA) or other sorbents for purifying the extract (Figure 1). This methodology shows advantages over traditional pesticide analysis as it requires only a small amount of reagents, and sample isolation and cleanup are achieved in a single step instead of a series of time-consuming solvent extractions. Furthermore, acetonitrile is the preferred solvent for QuEChERS instead of toxic organochlorine solvents, making QuEChERS more environmentally friendly. In addition, the acetonitrile extracts produced are versatile and can be analyzed by liquid or gas chromatography, and recoveries are generally high (Figure 2). Thus, the methodology has been modified for analyzing various pesticides including pyrethroids, organochlorine, and phosphorous pesticides in various food matrices [2].

QuEChERS was originally developed as a multiclass residue method for determining pesticides in fruits and vegetables [1]. Because fruits and vegetables have high water content and are low in fat, application of QuEChERS for pesticide analysis in other food matrices requires modifications. QuEChERS was adapted for analyzing pesticides in cereals by adding water to the dry ground sample, producing slurry for extraction [6], whereas $C_{18}$ was added for removing interfering lipids in oily samples like flaxseeds and peanuts [7].

Because pesticides are not the only xenobiotics in foodstuffs, analysis of veterinary drugs, mycotoxins, and other contaminants cannot be neglected. So far, QuEChERS has been predominantly applied for the analysis of contaminants in foods of plant origin. In addition to pesticides in various fruits and vegetables [2], acrylamide in potato 


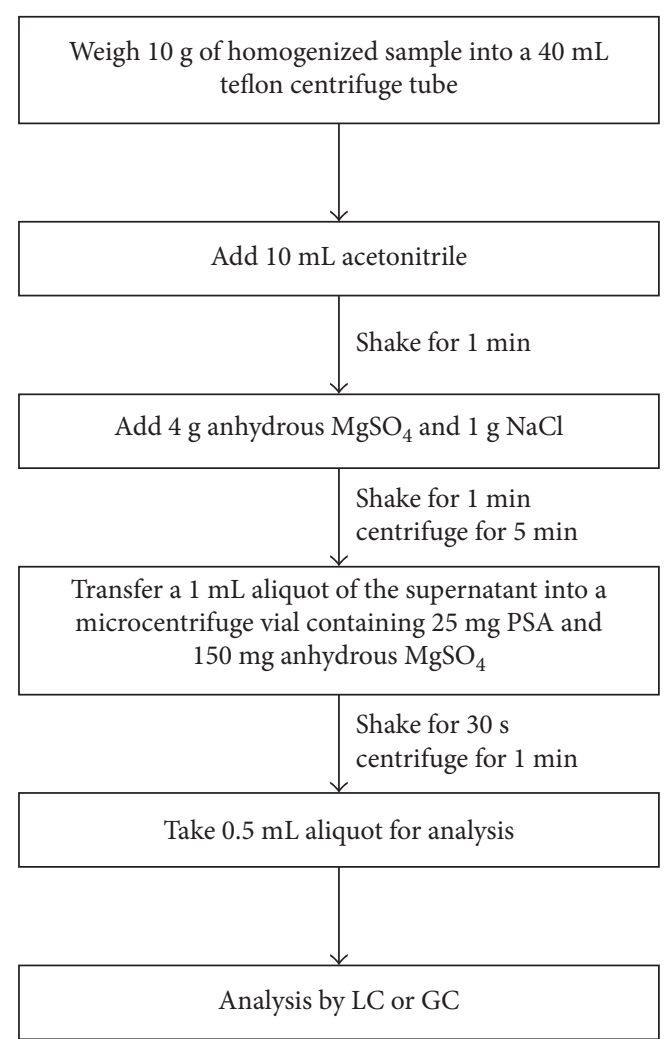

Figure 1: Flowchart of the QuEChERS method (based on [1] and $[2])$.

chips, peanut butter, and chocolate [8] and aflatoxins in noodles [9] have been determined using QuEChERS.

QuEChERS has been demonstrated to be an effective and versatile technique and has also been recently applied for the analysis of various xenobiotics in animal products. The complexity of animal tissues and milk as well as the presence of fat are challenges to overcome for the successful analysis of xenobiotics in such matrices. Although several matrixspecific methods are reported here, it is noteworthy that a simple, modular QuEChERS method was developed for analyzing pesticides in animal products with various contents of fat, attaining adequate recoveries that could make it a good option for routine sample screening; this method involved extraction of the sample in acetonitrile, followed by hexane extraction in the presence of a QuEChERS salt and cleanup by $\operatorname{SPE}\left(\mathrm{C}_{18}\right)$ [10].

Therefore, this review presents a compilation of examples of the application of QuEChERS to the analysis of xenobiotics including pesticides, mycotoxins, and veterinary drugs in animal products such as meat, milk, eggs, and honey (Table 1). Because new studies on this topic are increasingly appearing in the literature, the list is not exhaustive but focuses on major products and xenobiotics of concern as well as reports from the previous 5 years. It is expected that this review will provide information about the use of QuEChERS as an alternative technique for the analysis of various contaminants in food products of animal origin. In addition, considerations about solvent and sorbent selection are presented.

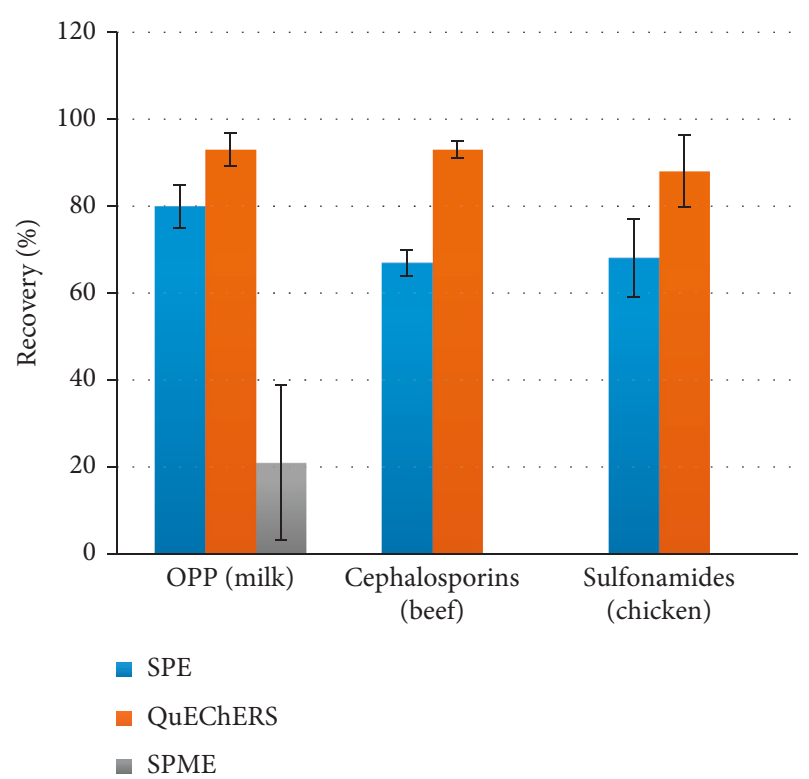

FIGURE 2: Comparison of the recoveries obtained using QuEChERS with those obtained with other extraction methods (OPP: organophosphate pesticides, SPE: solid-phase extraction, SPME: solid-phase microextraction) for selected classes of compounds according to published data [3-5].

\section{Application of QuEChERS to Foods of Animal Origin}

2.1. Meat. Veterinary drug residues are xenobiotics of concern in meat products. These drugs include antibiotics, antiparasitic agents, compounds that stimulate muscle production, growth hormones, and anti-inflammatories. Residues of pesticides and tranquilizers can also be found in meat, and dangerous compounds like nitrosamines can be present in processed meat products. Therefore, monitoring of these substances in meat is crucial.

The first report of QuEChERS applied to animal tissues described the analysis of $\beta$-lactam antibiotics in bovine kidneys [49]. $\beta$-Lactams include penicillins and cephalosporins and are used to treat bacterial infections as well as to promote weight gain in farm animals. The presence of antibiotic residues in meat is also of concern as it may trigger adverse reactions in hypersensitive individuals [50]. Thus, effective methods are required to monitor these compounds and ensure that they are not present in foods at levels above those considered safe. In the study by Fagerquist et al. [49], QuEChERS extraction was achieved using water and acetonitrile, and $\mathrm{C}_{18}$ was added to remove interfering fats; subsequently, the extract was analyzed by LC-MS/MS. LC$\mathrm{MS} / \mathrm{MS}$ is the technique of choice for detecting drug residues because it can determine compounds with high molecular mass as well as polar, nonvolatile, and heat-sensitive compounds [11]. Another report described the analysis of cephalosporins in beef muscle by LC-MS/MS after QuEChERS extraction using $\mathrm{C}_{18}, \mathrm{PSA}$, and $\mathrm{MgSO}_{4}$ as sorbents for d-SPE [3]; the proposed QuEChERS method was comparable to SPE and sensitive enough to comply with European Union regulations. 
TABLE 1: Summary of applications of QuEChERS for the analysis of xenobiotics in animal products.

\begin{tabular}{|c|c|c|c|c|}
\hline Matrix & Analytes & QuEChERS method & Analytical method & Ref. \\
\hline $\begin{array}{l}\text { Goat's milk } \\
\text { and sheep } \\
\text { muscle }\end{array}$ & $\begin{array}{l}\text { Monepantel } \\
\text { and its sulfone } \\
\text { metabolite }\end{array}$ & 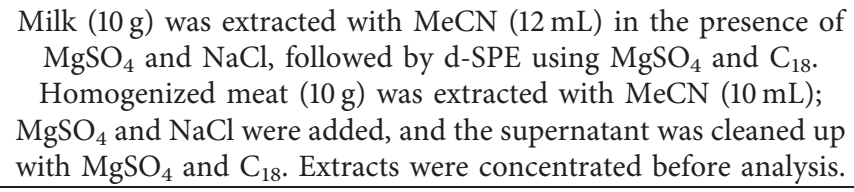 & UPLC-MS/MS & [11] \\
\hline Beef muscle & Cephalosporins & $\begin{array}{c}\text { Homogenized beef }(4 \mathrm{~g}) \text { was extracted with } 15 \mathrm{~mL} \text { of } \mathrm{MeCN} / \text { water } \\
(80: 20) \text {; d-SPE was performed using } \mathrm{C}_{18}, \mathrm{PSA} \text { and } \mathrm{MgSO}_{4} \text {. The } \\
\text { sample was dried and reconstituted before analysis. }\end{array}$ & LC-MS/MS & {$[3]$} \\
\hline $\begin{array}{l}\text { Meat and } \\
\text { bovine fat }\end{array}$ & $\begin{array}{l}\text { Chlorfenvinphos, } \\
\text { fipronil, and } \\
\text { cypermethrin }\end{array}$ & $\begin{array}{l}\text { For the meat, } 2 \mathrm{~g} \text { of homogenized sample was extracted in } 4 \mathrm{~mL} \\
\text { of } \mathrm{MeCN} \text { in the presence of } \mathrm{MgSO}_{4} \text { and } \mathrm{NaCl} \text {, followed by d-SPE } \\
\text { with } \mathrm{C}_{18}, \mathrm{PSA} \text {, and } \mathrm{MgSO}_{4} \text {. For the fat, } 1 \mathrm{~g} \text { of homogenized sample } \\
\text { was extracted in } 5 \mathrm{~mL} \text { of hexane }+10 \mathrm{~mL} \text { of water }+10 \mathrm{~mL} \text { of } \mathrm{MeCN} \\
\text { in the presence of } \mathrm{MgSO}_{4} \text { and } \mathrm{NaCl} \text {, followed by d-SPE with PSA } \\
\text { and } \mathrm{MgSO}_{4} \text {. }\end{array}$ & GC-MS & {$[12]$} \\
\hline Bacon & Nitrites & $\begin{array}{l}\text { Comminuted cooked bacon }(5 \mathrm{~g}) \text { was extracted with } 10 \mathrm{~mL} \text { of } \\
\mathrm{MeCN} / \text { water }(1: 1) \text { in the presence of } \mathrm{HCO}_{2} \mathrm{NH}_{4} \text {, followed by } \\
\mathrm{d}-\mathrm{SPE} \text { using } \mathrm{MgSO}_{4}, \mathrm{PSA}, \mathrm{C}_{18} \text {, and } \mathrm{Z} \text {-Sep sorbents. Coextracted } \\
\text { lipids were removed by hexane partitioning. }\end{array}$ & GC-MS/MS & [13] \\
\hline $\begin{array}{l}\text { Meat } \\
\text { products }\end{array}$ & $\begin{array}{l}\text { Polychlorinated } \\
\text { biphenyls (PCBs) }\end{array}$ & $\begin{array}{l}\text { Melted fat sample }(1 \mathrm{~g}) \text { was extracted with } 7 \mathrm{~mL} \text { of acetone. The } \\
\text { supernatant was dried and collected using } 2 \mathrm{~mL} \text { of acetonitrile in } \\
\text { the presence of PSA and } \mathrm{MgSO}_{4} \text {. The sample was dried and } \\
\text { collected using isooctane before injection. }\end{array}$ & GC-MS & {$[14]$} \\
\hline $\begin{array}{l}\text { Sheep } \\
\text { meat }\end{array}$ & $\begin{array}{l}\text { Chlorinated } \\
\text { hydrocarbon } \\
\text { and synthetic } \\
\text { pyrethroids }\end{array}$ & $\begin{array}{l}\text { Homogenized meat }(10 \mathrm{~g}) \text { was extracted with } 20 \mathrm{~mL} \text { of } \mathrm{MeCN} \text { in } \\
\text { the presence of } \mathrm{MgSO}_{4} \text { and } \mathrm{NaCl} \text {, followed by d-SPE using PSA } \\
\text { and } \mathrm{MgSO}_{4} \text {. Samples were dried and redissolved before analysis. }\end{array}$ & GC-ECD & [15] \\
\hline Pork & Ractopamine & $\begin{array}{l}\text { Ground pork sample }(5 \mathrm{~g}) \text { was extracted with } 10 \mathrm{~mL} \text { of } 0.1 \% \mathrm{AcOH} \\
\text { in } \mathrm{MeCN} \text {, followed by cleanup using } \mathrm{MgSO}_{4}, \mathrm{NaCl}, \mathrm{C}_{18} \text {, and PSA. } \\
\text { Samples were dried and redissolved before analysis. }\end{array}$ & LC-MS & [16] \\
\hline Pork & Methenamine & $\begin{array}{l}\text { Homogenized sample }(2 \mathrm{~g}) \text { was extracted with } 10 \mathrm{~mL} \text { of } \mathrm{MeCN} \\
\text { in the presence of } \mathrm{Na}_{2} \mathrm{SO}_{4} \text {, followed by extraction with } \\
\text { MeCN-saturated hexane. The MeCN was cleaned up with PSA. }\end{array}$ & LC-MS/MS & {$[17]$} \\
\hline Chicken & $\begin{array}{l}\text { Amantadine } \\
\text { and rimantadine }\end{array}$ & $\begin{array}{c}\text { Homogenized chicken meat }(3 \mathrm{~g}) \text { was extracted with } 10 \mathrm{~mL} \text { of } \\
1 \% \mathrm{AcOH} \text { in } \mathrm{MeCN} \text { in the presence of } \mathrm{NaCl} \text { and } \mathrm{MgSO}_{4} \text {, followed } \\
\text { by d-SPE using } \mathrm{C}_{18} \text {. The sample was dried and redissolved before } \\
\text { analysis. }\end{array}$ & $\begin{array}{l}\text { UHPLC-LTQ } \\
\text { Orbitrap MS }\end{array}$ & [18] \\
\hline Chicken & $\begin{array}{l}\text { Antiviral drugs } \\
\text { and relevant } \\
\text { metabolites }\end{array}$ & $\begin{array}{l}\text { Homogenized chicken meat }(2 \mathrm{~g}) \text { was extracted with } 9 \mathrm{~mL} \text { of } \\
1 \% \mathrm{AcOH} \text { in } \mathrm{MeCN}+1 \mathrm{~mL} \text { of water. The supernatant was split into } \\
\text { two portions for the analysis of different compounds and dried. } \\
\text { One portion was redissolved in } \mathrm{MeOH} / \text { water and the other in } \\
\text { water. The extracts were cleaned up using PSA. }\end{array}$ & UPLC-MS/MS & [19] \\
\hline Chicken & Veterinary drugs & $\begin{array}{c}\text { Homogenized chicken meat }(5 \mathrm{~g}) \text { was extracted with } 10 \mathrm{~mL} \text { of } \\
1 \% \mathrm{AcOH} \text { in } \mathrm{MeCN} \text { : water }(80: 20) \text { in the presence of } \\
\mathrm{Na}_{2} \mathrm{HCit} \cdot 1.5 \mathrm{H}_{2} \mathrm{O}, \mathrm{Na}_{3} \mathrm{Cit} \cdot 2 \mathrm{H}_{2} \mathrm{O} \text {, and } \mathrm{MgSO}_{4} \text {, followed by d-SPE } \\
\text { using PSA. }\end{array}$ & UHPLC-MS/MS & [20] \\
\hline Chicken & Sulfonamides & $\begin{array}{c}\text { Homogenized chicken meat }(10 \mathrm{~g}) \text { was extracted with } 15 \mathrm{~mL} \text { of } \\
1 \% \mathrm{AcOH} \text { in } \mathrm{MeCN} \text { in the presence of } \mathrm{NaOAc} \text { and } \mathrm{MgSO}_{4} \text {, } \\
\text { followed by d-SPE using PSA and } \mathrm{MgSO}_{4} \text {. The sample was } \\
\text { concentrated before analysis }\end{array}$ & HPLC-DAD & {$[4]$} \\
\hline $\begin{array}{l}\text { Milk and } \\
\text { honey }\end{array}$ & $\begin{array}{l}\text { Chloramphenicol, } \\
\text { thiamphenicol, } \\
\text { and florfenicol }\end{array}$ & $\begin{array}{c}\text { Sample }(2 \mathrm{~g}) \text { was extracted with } 15 \mathrm{~mL} \text { of } 0.1 \% \mathrm{AcOH} \text { in } \mathrm{MeCN} \text { in } \\
\text { the presence of } \mathrm{Na}_{2} \mathrm{SO}_{4} \text { and } \mathrm{NaCl} \text {, followed by d-SPE using } \\
\mathrm{Na}_{2} \mathrm{SO}_{4}, \mathrm{C}_{18} \text {, and QuE Z-Sep }{ }^{+} \text {. Samples were dried and } \\
\text { reconstituted before analysis. }\end{array}$ & LC-MS/MS & {$[21]$} \\
\hline Milk & $\begin{array}{c}\text { Anabolic steroids } \\
\text { and agonists }\end{array}$ & $\begin{array}{l}\text { Milk ( } 5 \mathrm{~g} \text { ) was extracted with } 10 \mathrm{~mL} \text { of } 5 \% \mathrm{AcOH} \text { in } \mathrm{MeCN} \text { in the } \\
\text { presence of } \mathrm{ZnO} \text { nanoparticles, followed by d-SPE using PSA. } \\
\text { Samples were dried and redissolved before analysis. }\end{array}$ & UHPLC-MS/MS & [22] \\
\hline
\end{tabular}


Table 1: Continued.

\begin{tabular}{|c|c|c|c|c|}
\hline Matrix & Analytes & QuEChERS method & Analytical method & Ref. \\
\hline $\begin{array}{l}\text { Yogurt } \\
\text { and milk }\end{array}$ & $\begin{array}{l}\text { Herbicides } \\
\text { (triazines and } \\
\text { phenylureas) }\end{array}$ & $\begin{array}{l}\text { Sample }(5 \mathrm{~mL}) \text { was adjusted to } \mathrm{pH} 7 \text { and extracted with } 8 \mathrm{~mL} \\
\text { EtOAc/hexane }(1: 1) \text { in the presence of } \mathrm{NaCl} \text {, followed by d-SPE } \\
\text { using PSA. The extract was dried and redissolved before analysis. }\end{array}$ & HPLC-DAD & {$[23]$} \\
\hline Milk & Pesticides & $\begin{array}{l}\text { Milk ( } 15 \mathrm{~g} \text { ) was extracted with } 15 \mathrm{~mL} \text { of } 0.1 \% \mathrm{AcOH} \text { in } \mathrm{MeCN} \text { in the } \\
\text { presence of } \mathrm{NaOAc} \text { and } \mathrm{MgSO}_{4} \text {, followed by d-SPE using } \mathrm{MgSO}_{4} \text {, } \\
\qquad \mathrm{PSA} \text { and } \mathrm{C}_{18} \text {. }\end{array}$ & $\begin{array}{l}\text { GC-ECD and } \\
\text { GC-MS }\end{array}$ & {$[24]$} \\
\hline Milk & Pesticides & $\begin{array}{l}\text { Milk }(20 \mathrm{~mL}) \text { was extracted with } 16 \mathrm{~mL} \mathrm{MeCN} \text { in the presence of } \\
\mathrm{NaCl} \text { and } \mathrm{MgSO}_{4} \text {. The extract was dried and reconstituted, } \\
\text { followed by d-SPE using PSA, Z-Sep, and Z-Sep Plus. The } \\
\text { supernatant was dried and redissolved before analysis. }\end{array}$ & HPLC-DAD & {$[25]$} \\
\hline $\begin{array}{l}\text { Raw milk } \\
\text { (cow, goat, } \\
\text { and buffalo } \\
\text { milk) }\end{array}$ & $\begin{array}{l}\text { Steroid } \\
\text { hormones }\end{array}$ & $\begin{array}{l}\text { Milk (10 g) was extracted with } 10 \mathrm{~mL} \mathrm{MeCN} \text { in the presence of } \\
\mathrm{NaCl}, \mathrm{Na}_{2} \mathrm{HCit}, \mathrm{Na}_{2} \mathrm{HCit} 1.5 \mathrm{H}_{2} \mathrm{O} \text {, and } \mathrm{MgSO}_{4} \text {, followed by d-SPE } \\
\text { using } \mathrm{MgSO}_{4}, \mathrm{PSA} \text {, and acidic alumina. }\end{array}$ & UPLC-QTOF-MS & {$[26]$} \\
\hline Milk & Sulfonamides & $\begin{array}{l}\text { Milk }(10 \mathrm{~g}) \text { was extracted with } 10 \mathrm{~mL} \text { of } 1 \% \mathrm{AcOH} \text { in } \mathrm{MeCN} \\
+10 \mathrm{~mL} 0.1 \mathrm{M} \text { EDTA in the presence of } \mathrm{NaOAc} \text { and } \mathrm{MgSO}_{4} \text {. }\end{array}$ & LC/MS/MS & {$[27]$} \\
\hline Eggs & $\begin{array}{l}\text { Aflatoxins } \\
\text { B1, G1, B2, G2, } \\
\text { zearalenone, and } \\
\text { its metabolites }\end{array}$ & $\begin{array}{l}\text { Homogenized eggs }(2 \mathrm{~g})+2 \mathrm{~mL} \text { water was extracted with } 10 \mathrm{~mL} \text { of } \\
1 \% \mathrm{AcOH} \text { in } \mathrm{MeCN} \text { in the presence of } \mathrm{MgSO}_{4} \text { and } \mathrm{NaCl} \text {, followed } \\
\text { by d-SPE using } \mathrm{MgSO}_{4} \text { and } \mathrm{C}_{18} \text {. The extract was dried and } \\
\text { redissolved before analysis. }\end{array}$ & UPLC-MS/MS & {$[28]$} \\
\hline Eggs & $\begin{array}{l}\text { Melamine and } \\
\text { cyromazine }\end{array}$ & $\begin{array}{l}\text { Homogenized egg yolk }(0.5 \mathrm{~g}) \text { was extracted with } 1 \mathrm{~mL} \mathrm{MeCN} \\
+1 \mathrm{~mL} \mathrm{MeOH} \text { in the presence of QuEChERS sorbent for fatty } \\
\text { samples. The extract was dried and redissolved before analysis. }\end{array}$ & HPLC-DAD & [29] \\
\hline Eggs & $\begin{array}{l}\text { Melamine and } \\
\text { cyromazine }\end{array}$ & $\begin{array}{l}\text { Homogenized egg sample }(1 \mathrm{~g}) \text { was extracted with } 5 \mathrm{~mL} \mathrm{MeCN} \\
+0.1 \mathrm{M} \mathrm{HCl}(99.5: 0.5) \text {, followed by d-SPE using } \mathrm{MgSO}_{4} \text { and GCB. } \\
\text { The extract was dried and redissolved before analysis. }\end{array}$ & LC-MS/MS & {$[30]$} \\
\hline Eggs & Mycotoxins & $\begin{array}{l}\text { Homogenized egg }(2 \mathrm{~g}) \text { was extracted with } 10 \mathrm{~mL} \text { of } \mathrm{MeOH} / \text { water } \\
(80: 20) \text { with } 1 \% \mathrm{AcOH}, \mathrm{Na}_{2} \mathrm{SO}_{4} \text {, and } \mathrm{NaOAc} \text {, without d-SPE. }\end{array}$ & UHPLC-MS/MS & {$[31]$} \\
\hline $\begin{array}{l}\text { Eggs and } \\
\text { egg products }\end{array}$ & Pesticides & $\begin{array}{l}\text { Homogenized egg ( } 5 \mathrm{~g}) \text { was extracted with } 1 \% \mathrm{AcOH} \text { in } \mathrm{MeCN} \\
(15 \mathrm{~mL}) \text { in the presence of } \mathrm{MgSO}_{4} \text { and NaOAc, followed by d-SPE } \\
\text { with } \mathrm{MgSO}_{4}, \mathrm{C}_{18} \text {, PSA, and GCB. The extract was dried and } \\
\text { redissolved before analysis. } \\
\text { In the case of egg yolk, } 2.5 \mathrm{~g} \text { of homogenized sample }+2.5 \mathrm{~mL} \text { of } \\
\text { deionized water were mixed prior to extraction, performed as } \\
\text { above. Powdered egg white was diluted to } 12.3 \% \mathrm{w} / \mathrm{v} \text { with } \\
\text { deionized water, and a } 5 \mathrm{~g} \text { sample was extracted as above. }\end{array}$ & LC-MS/MS & {$[32]$} \\
\hline $\begin{array}{l}\text { Eggs, chicken, } \\
\text { and pork }\end{array}$ & $\begin{array}{l}\text { Phorate } \\
\text { and its } \\
\text { metabolites }\end{array}$ & $\begin{array}{l}\text { Homogenized sample }(5 \mathrm{~g}) \text { was extracted with } 15 \mathrm{~mL} \text { of } 1 \% \mathrm{AcOH} \\
\text { in } \mathrm{MeCN} \text { in the presence of } \mathrm{MgSO}_{4} \text { and NaOAc; the supernatant } \\
\text { was reextracted with } 1 \% \mathrm{AcOH} \text { in } \mathrm{MeCN}_{\text {, cleaned up with } \mathrm{MgSO}_{4} \text {, }} \text { PSA, and } \mathrm{C}_{18} \text {. The extract was dried and redissolved before analysis. }\end{array}$ & UHPLC-MS/MS & {$[33]$} \\
\hline $\begin{array}{l}\text { Fish (tilapia } \\
\text { and salmon) }\end{array}$ & $\begin{array}{l}\text { Organochlorine } \\
\text { pesticides and } \\
\text { polychlorinated } \\
\text { biphenyls }\end{array}$ & $\begin{array}{l}\text { Homogenized fish }(5 \mathrm{~g}) \text { was extracted with } 10 \mathrm{~mL} \text { of Milli-Q water } \\
+10 \mathrm{~mL} \text { of } \mathrm{MeCN} \text { in the presence of } \mathrm{MgSO}_{4}, \mathrm{NaCl} \text {, } \\
\mathrm{Na}_{2} \mathrm{HCit} \cdot 1.5 \mathrm{H}_{2} \mathrm{O} \text {, and } \mathrm{Na}_{3} \mathrm{Cit} \cdot 2 \mathrm{H}_{2} \mathrm{O} \text {. The supernatant was frozen } \\
\text { and partitioned in } \mathrm{CaCl}_{2} \text {, followed by a second cleanup with } \\
\qquad \mathrm{MgSO}_{4} \text { and PSA. }\end{array}$ & GC-MS & {$[34]$} \\
\hline Fish & $\begin{array}{l}\text { Organochlorine } \\
\text { pesticides }\end{array}$ & $\begin{array}{l}\text { Homogenized fish }(5 \mathrm{~g}) \text { was extracted with } \mathrm{MeCN}(10 \mathrm{~mL}) \text { in the } \\
\text { presence of } \mathrm{MgSO}_{4} \text { and } \mathrm{NaCl} \text {, followed by } \mathrm{d} \text {-SPE using PSA. Then, } \\
\text { water and } 1 \text {-undecanol were added, and the sample was cooled in } \\
\text { an ice bath to separate the organic phase. }\end{array}$ & GC-MS & {$[35]$} \\
\hline $\begin{array}{l}\text { High-fat } \\
\text { smoked } \\
\text { salmon }\end{array}$ & $\begin{array}{l}\text { Parent and } \\
\text { substituted } \\
\text { polycyclic aromatic } \\
\text { hydrocarbons }\end{array}$ & $\begin{array}{l}\text { Four QuEChERS extraction methods were tested. Optimized } \\
\text { QuEChERS involved extraction with } 2: 2: 1(\mathrm{v} / \mathrm{v} / \mathrm{v}) \text { acetone/ethyl } \\
\text { acetate/isooctane in the presence of AOAC or EN salts, followed by } \\
\text { d-SPE with Sampli-Q AOAC fatty sample d-SPE tubes. }\end{array}$ & GC-MS & {$[36]$} \\
\hline $\begin{array}{l}\text { Fish muscle } \\
\text { and liver } \\
\text { tissues }\end{array}$ & $\begin{array}{l}\text { Personal care } \\
\text { products (biocides, } \\
\text { synthetic musks, } \\
\text { and benzotriazoles) }\end{array}$ & $\begin{array}{l}\text { Homogenized fish muscle }(2 \mathrm{~g}) \text { or fish liver }(0.5 \mathrm{~g}) \text { was extracted } \\
\text { with } 1 \% \mathrm{AcOH} \text { in } \mathrm{MeCN}(10 \mathrm{~mL}) \text { in the presence of } \mathrm{MgSO}_{4} \text { and } \\
\mathrm{NaOAc} \text {, followed by d-SPE using PSA, } \mathrm{MgSO}_{4} \text {, and } \mathrm{C}_{18} \text {. The } \\
\text { sample was evaporated and redissolved before analysis. }\end{array}$ & $\begin{array}{l}\text { UPLC-MS/MS } \\
\text { and GC-MS }\end{array}$ & {$[37]$} \\
\hline
\end{tabular}


TABle 1: Continued.

\begin{tabular}{|c|c|c|c|c|}
\hline Matrix & Analytes & QuEChERS method & Analytical method & Ref. \\
\hline $\begin{array}{l}\text { Fish (carp } \\
\text { and sturgeon) }\end{array}$ & $\begin{array}{l}\text { Organochlorine and } \\
\text { organophosphate } \\
\text { pesticides }\end{array}$ & $\begin{array}{c}\text { Homogenized fish muscle }(5 \mathrm{~g}) \text { was extracted with } \mathrm{MeCN}(10 \mathrm{~mL}) \\
\text { in the presence of } \mathrm{Na}_{2} \mathrm{HCit} \cdot 1.5 \mathrm{H}_{2} \mathrm{O}, \mathrm{Na}_{3} \mathrm{Cit} \cdot 2 \mathrm{H}_{2} \mathrm{O}, \mathrm{NaCl}, \\
\text { and } \mathrm{MgSO}_{4} \text {. A dual d-SPE cleanup was performed, using } \\
\text { PSA + } \mathrm{SAX}+\mathrm{NH}_{2} \text {, followed by } \mathrm{C}_{18} \text { and } \mathrm{CHCl}_{3} \text { addition and } \\
\text { freezing-out to remove fats. }\end{array}$ & GC/Q-MS & {$[38]$} \\
\hline Fish (catfish) & PCBs & $\begin{array}{l}\text { Homogenized sample }(3 \mathrm{~g}) \text { was extracted with water }(5 \mathrm{~mL}) \text { and } \\
\text { MeCN (30 mL) in the presence of } \mathrm{MgSO}_{4} \text { and } \mathrm{NaCl} \text {; } \mathrm{d} \text {-SPE was } \\
\text { performed with } \mathrm{MgSO}_{4}, \mathrm{PSA}_{\text {, and } \mathrm{C}_{18} \text {. }}\end{array}$ & GC-MS & [39] \\
\hline Fish & Quinolones & $\begin{array}{l}\text { Homogenized fish }(5 \mathrm{~g}) \text { was extracted with } 5 \% \mathrm{HCOOH} \text { in } \mathrm{MeCN} \\
(10 \mathrm{~mL}) \text { in the presence of } \mathrm{MgSO}_{4}, \mathrm{NaCl}, \mathrm{NaOAc} \text {, and } \\
\mathrm{Na}_{2} \mathrm{HCit} \cdot 1.5 \mathrm{H}_{2} \mathrm{O} \text {, followed by d-SPE using } \mathrm{C}_{18} \text { and } \mathrm{MgSO}_{4} \text {. The } \\
\text { extract was dried and redissolved before analysis. }\end{array}$ & UHPLC-FLD & {$[40]$} \\
\hline Fish & $\begin{array}{l}\text { Organochlorine } \\
\text { pesticides }\end{array}$ & $\begin{array}{l}\text { Homogenized fish }(5 \mathrm{~g}) \text { was extracted with } \mathrm{MeCN}(5 \mathrm{~mL}) \text { in the } \\
\text { presence of } \mathrm{MgSO}_{4} \text { and } \mathrm{NaCl} \text {, followed by d-SPE with PSA } \\
\text { + DLLME-SFO with 1-undecanol + water, and the sample was } \\
\text { cooled in an ice bath to separate the organic phase. }\end{array}$ & GC-ECD & {$[41]$} \\
\hline Bivalves & Pharmaceuticals & $\begin{array}{l}\text { Frozen-dried sample }(1 \mathrm{~g}) \text { was mixed with } 10 \mathrm{~mL} \text { water and } \\
\text { extracted with MeCN }(10 \mathrm{~mL}) \text { in the presence of EN salts, followed } \\
\text { by cleanup with silica gel. The extract was dried and redissolved } \\
\text { before analysis. }\end{array}$ & LC-MS/MS & {$[42]$} \\
\hline Bivalves & $\begin{array}{l}\text { Paralytic shellfish } \\
\text { poisoning toxins }\end{array}$ & $\begin{array}{l}\text { Homogenized sample }(1 \mathrm{~g}) \text { was extracted twice with } 1 \% \mathrm{HCOOH} \\
(1 \mathrm{~mL}) \text {; protein was precipitated and } \mathrm{d}-\mathrm{SPE} \text { was performed using } \\
\text { ABS Elut-NEXUS phase. }\end{array}$ & LC-MS & {$[43]$} \\
\hline Honey & $\begin{array}{l}\text { Nitrofuran } \\
\text { metabolites and } \\
\text { nitroimidazole }\end{array}$ & $\begin{array}{l}\text { Honey }(1 \mathrm{~g}) \text { was extracted using } 10 \mathrm{~mL} \mathrm{MeCN} \text { with } \mathrm{MgSO}_{4} \text { and } \\
\mathrm{NaCl} \text {, without d-SPE. The extract was evaporated and redissolved } \\
\text { before analysis. }\end{array}$ & LC-MS/MS & {$[44]$} \\
\hline Honey & Pesticides & $\begin{array}{l}\text { Honey }(2.5 \mathrm{~g}) \text { was heated in a water bath and extracted with } 5 \mathrm{~mL} \\
\mathrm{Na}_{2} \mathrm{EDTA}+5.0 \mathrm{~mL} \mathrm{MeCN} \text { in the presence of } \mathrm{MgSO}_{4} \text { and } \mathrm{NaCl} \text {, } \\
\text { followed by d-SPE using PSA and } \mathrm{MgSO}_{4} \text {. }\end{array}$ & GC-ECD & {$[45]$} \\
\hline Honey & Pesticides & $\begin{array}{l}\text { Honey }(5 \mathrm{~g}) \text { dissolved in } 10 \mathrm{~mL} \text { water was extracted with } 10 \mathrm{~mL} 1 \% \\
\mathrm{AcOH} \text { in MeCN:EtOAc }(70: 30) \text {, in the presence of } \mathrm{MgSO}_{4} \text { and } \\
\mathrm{NaOAc} \text {, followed by d-SPE using } \mathrm{MgSO}_{4} \text {, Florisil, and PSA. }\end{array}$ & UHPLC-MS/MS & {$[46]$} \\
\hline Honey & $\begin{array}{c}\text { Pesticides, } \\
\text { PAHs, and PCBs }\end{array}$ & $\begin{array}{l}\text { Honey }(5 \mathrm{~g} \text { ) dissolved in } 10 \mathrm{~mL} \text { water was extracted with } 10 \mathrm{~mL} \\
\text { MeCN in the presence of citrate salts, followed by d-SPE using } \\
\text { PSA. Extracts were evaporated and redissolved; one part was } \\
\text { directly analyzed by LC, whereas the other part was diluted with } \\
\text { salted water and extracted with SPME for GC analysis. }\end{array}$ & $\begin{array}{l}\text { LC-MS/MS, } \\
\text { GC-MS/MS }\end{array}$ & {$[47]$} \\
\hline Honey & $\begin{array}{l}\text { Pyrrolizidine } \\
\text { and tropane } \\
\text { alkaloids }\end{array}$ & $\begin{array}{l}\text { Homogenized honey }(1.5 \mathrm{~g}) \text { was dissolved with } 0.1 \mathrm{M} \mathrm{H}_{2} \mathrm{SO}_{4} \\
(10 \mathrm{~mL}) \text {, and } \mathrm{Zn} \text { dust was added. After centrifugation, the sample } \\
\text { was extracted with } 10 \mathrm{~mL} \mathrm{MeCN} \text { in the presence of EN salts, } \\
\text { followed by d-SPE with Q-Sep sorbent. The extract was dried and } \\
\text { redissolved before analysis. }\end{array}$ & LC-HRMS & {$[48]$} \\
\hline
\end{tabular}

Antiparasitic drugs are administered to farm animals to control roundworm infections. Some common anthelmintic drugs include benzimidazoles, macrocyclic lactones, and amino-acetonitrile derivatives. As with antibiotics, residues of these compounds can show up in meat and milk and should thus be monitored. Kinsella et al. [11] reported a modified QuEChERS method for detecting the anthelmintic monepantel and its sulfone metabolite in both sheep meat and goat's milk. Their method added a concentration step to increase sensitivity, and samples were analyzed by UHPLC-MS/MS. The method showed fast separation (13 $\mathrm{min}$ ) and good recoveries (108\%-109\%) for both monepantel and its metabolite.
QuEChERS can also be used to detect the presence of residues of banned feed additives that could appear in animal products. Ractopamine is a $\beta$-agonist used as a feed additive for finishing pigs as it promotes the production of muscle instead of fat. Nevertheless, $\beta$-agonists may produce toxic effects on the cardiovascular system [51], and ractopamine has been banned in Europe and parts of Asia. A Brazilian team quantified ractopamine in pork by QuEChERS-LC-MS/MS [16] in only $4.5 \mathrm{~min}$, which represents substantial time savings compared to conventional ractopamine analysis, which is performed by liquid-liquid extraction followed by derivatization and GC-MS analysis [52] or liquid-liquid extraction followed by HPLC or LC-MS 
$[53,54]$. In addition to being fast, the QuEChERS method of Valese et al. [16] achieved adequate recoveries (70\%-110\%) by using acidified ( $0.1 \%$ acetic acid) acetonitrile for the extraction and a low LOD $(1.5 \mu \mathrm{g} / \mathrm{kg})$. Ten $\beta$-agonists including ractopamine were simultaneously determined in beef and goat meat by a similar QuEChERS-LC-MS/MS method, which used a DVB-NVP-SO ${ }_{3} \mathrm{Na}$ sorbent for d-SPE [55]; in this study, a preconcentration step was performed to enhance sensitivity, achieving an even lower LOD $(0.3 \mu \mathrm{g} / \mathrm{kg})$ than that of Valese et al. [16].

As previously mentioned, the QuEChERS methodology was originally developed for the analysis of pesticide residues in vegetables and fruits and has been successfully applied for determining pesticides in various foodstuffs. Examples of QuEChERS application for determining pesticide residues in meat include the analysis of organochlorine pesticides and pyrethroids in sheep meat [15] and multiclass pesticide residues in beef and bovine fat [12]. Samples in these studies were analyzed by GC coupled to MS or ECD, and fat samples required partitioning in hexane prior to analysis. Recoveries were in the range $70 \%-129 \%$ with $\mathrm{RSD}<20 \%$.

In addition to organochlorine pesticides, polychlorinated biphenyls (PCBs) are other type of persistent organic pollutants that may contaminate meat. Even though PCBs were banned decades ago, their residues still appear in food products because of their stability and lipid-soluble properties; these compounds have harmful effects on human health including carcinogenicity, neurotoxicity, and developmental disorders in children. A QuEChERS-GC-MS method for determining PCBs in meat was optimized and successfully applied for analyzing processed meat products [14]; the method used ultrasonication to improve extraction efficiency and achieved LOQs below $1.3 \mathrm{ng} / \mathrm{g}$ (the MRL established by the European Community is $40 \mathrm{ng} / \mathrm{g}$ ) and high recoveries, representing a cheaper and environmentally friendly alternative for the analysis of PCBs.

Some harmful compounds are formed during meat processing or cooking. This is the case of nitrosamines, carcinogens produced when cooking cured meats. The US Department of Agriculture Food Service and Inspection Service (USDA-FSIS) has established a method for determining nitrosamines using supercritical fluid extraction followed by GC-thermal energy analysis (GC-TEA) [56]; however, this is a costly and tedious methodology, and better alternatives are needed. A new QuEChERS-GC-MS/MS methodology was developed for determining nitrosamines in cooked bacon, achieving good recoveries $(70 \%-120 \%)$ with low RSD $(<20 \%)$ [13], and was thus proposed to the USDA-FSIS as an efficient alternative for the monitoring of these compounds in bacon, an important source of exposure to nitrosamines in the American population.

2.2. Poultry. As with cattle, veterinary drugs are administered to chicken and other birds raised for food to fight infections and promote growth. Thus, residues of these substances must be monitored to ensure the safety of the meat and avoid potential harmful effects among consumers.
Sulfonamides, also known as sulfa drugs, are synthetic antibiotics used to combat bacterial infections. Nevertheless, allergic reactions to these drugs are common, and residues should be monitored to ensure they are not present at levels above those considered safe. A QuEChERS-HPLCDAD method for detecting sulfonamides in chicken breast was reported in 2013; the method attained LOQs below the MRL established by the European Community $(100 \mu \mathrm{g} / \mathrm{kg})$ and recoveries above $70 \%$ [4] by using buffering salts and concentrating the extract before analysis (Figure 3 ). A similar study used HPLC/FLD and Z-Sep ${ }^{+}$as a sorbent instead [57], also achieving LOQs below the established MRL, but the recoveries for some sulfonamides were slightly lower than those of Machado et al. [4]. A study using QuEChERS-LC-MS/MS described the simultaneous determination of 20 veterinary drug residues including several antibiotics and anthelmintics in chicken breast in less than $8.5 \mathrm{~min}[20]$.

Bird influenza is a serious problem that not only causes economic losses but also puts human health at risk. In the past, antiviral drugs were administered to chickens to protect them against influenza; however, the risk of resistance development by the influenza viruses, which would render drugs like Tamiflu ineffective, motivated several countries including the US and China to ban the use of antiviral drugs in poultry. Nevertheless, illegal use of antivirals in chicken still occurs, making it necessary to develop a method to detect residues of these drugs in chicken. Even though several methods for this purpose already exist, they generally require derivatization and tedious extraction procedures. A simultaneous determination of 14 antiviral drugs in chicken meat using QuEChERS-UPLC-MS/MS was reported [19]; the drugs monitored included antiviral drugs, antiherpes drugs, and an immunomodulator, and separation was achieved in less than $11 \mathrm{~min}$. Another report [18] described the optimization of a QuEChERS-UHPLC-LTQ Orbitrap MS method for detecting the antivirals amantadine and rimantadine in chicken breast.

2.3. Milk. Milk can be contaminated with pesticides when cows consume contaminated feed or water, and administration of veterinary drugs to the animals can result in the appearance of residues of antibiotics, hormones, anthelmintics, and other drugs in both milk and meat. Milk is an important component in the diet of children; hence, contamination with xenobiotics is of great concern. Milk is an emulsified fatty product; thus, both hydrophilic and hydrophobic xenobiotics can be present in it, making multiresidue analysis challenging. Therefore, an optimized QuEChERS methodology would save on cost and time when analyzing xenobiotics in milk. Response surface methodology was used to optimize the amount of sorbents $(\mathrm{NaOAc}$, PSA, and $\mathrm{C}_{18}$ ) used in a QuEChERS-GC-ECD method for the simultaneous determination of 14 pesticides in milk, achieving recoveries $>82 \%$ for hydrophilic pesticides, although recoveries of four lipophilic pesticides were $<80 \%$ [24]. In another study [25], PSA and $\mathrm{ZrO}_{2}$-based sorbents were used to purify the QuEChERS milk extracts before 


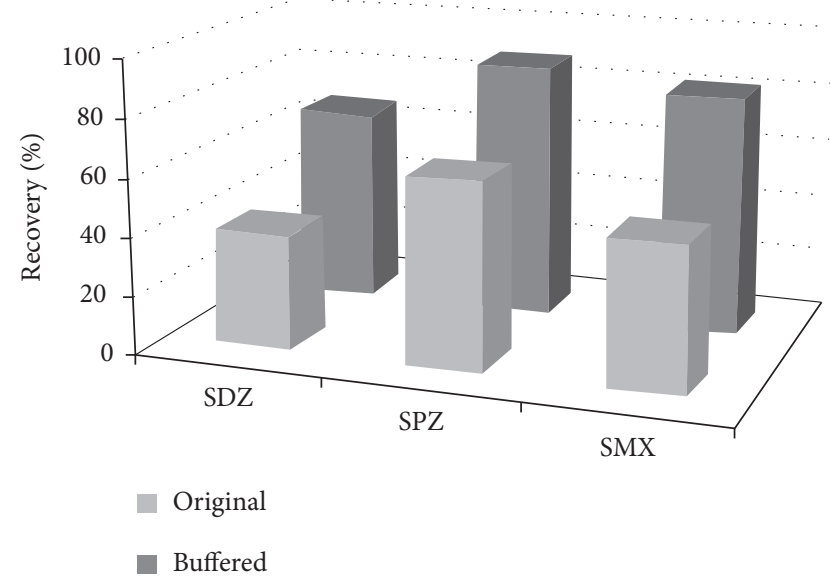

(a)

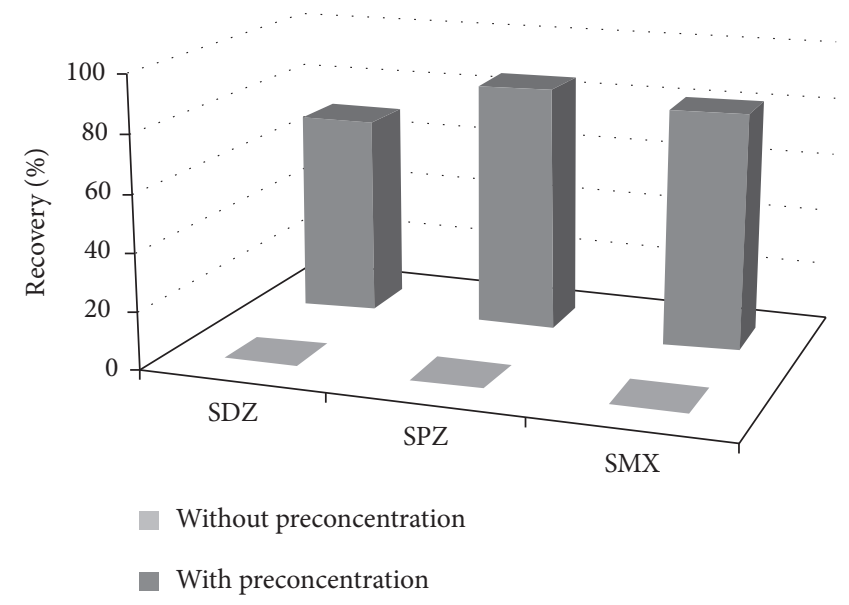

(b)

FIGURE 3: Effects of (a) using the original or buffered QuEChERS and (b) concentrating the extract on the recovery of sulfonamides (sulfadiazine (SDZ), sulfamethoxypyridazine (SPZ), and sulfamethoxazole (SMX)) from chicken. Taken from [4].

HPLC-DAD analysis for quantification of 30 pesticides, achieving a negligible matrix effect, adequate recoveries (70\%-100\%), and LOQs below the MRLs set by European regulations.

In addition, some QuEChERS-based methods for the analysis of veterinary drugs in milk have focused on particular compounds. Determination of the anthelmintic monepantel in milk using QuEChERS was reported by Kinsella et al. [11]. Another report focused on the determination of sulfonamides in milk [27], achieving a combined LOQ below the MRL set by the European Union $(100 \mu \mathrm{g} / \mathrm{kg})$.

The presence of hormone residues in milk is of concern because they have been associated with precocious puberty, breast cancer, and prostate cancer. Such residues occur by the, sometimes illegal, administration of hormones to cows to stimulate milk production. Hormone residues can be detected by ELISA; however, false positives are an issue. The low concentrations at which they occur and binding to proteins also hinder their detection by analytical equipment. A report described using PSA and $\mathrm{ZnO}$ nanoparticles as QuEChERS sorbents for the analysis of anabolic steroid and $\beta$-agonist residues in milk, using UHPLC-MS/MS [22]; application of the method to samples from Chinese markets revealed the presence of methyltestosterone, a banned substance, and other steroids. Another group of researchers used a combination of salts (anhydrous $\mathrm{MgSO}_{4}, \mathrm{NaCl}$, sodium citrate, and sodium citrate dibasic sesquihydrate) to cleanup cow, goat, and buffalo milk samples for the analysis of steroid hormones, using UPLC-TOF-MS for their determination [26]; application of this method to several Chinese milk samples revealed the presence of high levels of progesterone.

Aflatoxins are dangerous carcinogenic mycotoxins that can contaminate grains, oilseeds, and spices and can also appear in milk if the cow had consumed contaminated feed. QuEChERS proved to be useful for the analysis of aflatoxins in milk, using UPLC-MS/MS for their detection [58]; application of the optimized method revealed the presence of aflatoxins M1 and M2 in several powdered milk samples from Brazil, although at concentrations below the established maximum tolerance level (MTL).

QuEChERS has also been used in combination with other techniques to achieve purer extracts, facilitating the analysis of trace compounds. QuEChERS was used as a pretreatment step prior to capillary LC-MS/MS for determining chloramphenicol, thiamphenicol, and florfenicol in milk [21]. Chloramphenicol is a banned antibiotic in cattle in the European Union, which has set a minimum required performance limit (MRPL) of $0.3 \mathrm{ng} / \mathrm{g}$. To develop their modified QuEChERS method, Liu et al. [21] tested various sorbents, among which a combination of $\mathrm{Z}-\mathrm{Sep}^{+}$and $\mathrm{C}_{18}$ yielded excellent recoveries (96\%-100\%) (Figure 4), minor matrix effects, and low LODs $(\leq 0.045 \mathrm{ng} / \mathrm{g})$ representing a promising technique for the analysis of amphenicol traces in milk and similar products. In another study, QuEChERS was performed prior to dispersive liquid-liquid microextraction based on the solidification of the floating organic droplet (DLLME-SFO) method for determining organophosphorous pesticides in milk [5]; the method used 1dodecanol for the extraction instead of the organochlorine solvents generally used for DLLME, being more environmentally friendly and also allowing for easy and rapid analysis by GC.

2.4. Eggs. Eggs may contain many of the same xenobiotics found in chicken including antibiotics, hormones, and pesticides; nevertheless, the MRLs may differ as some products that are allowed in birds raised for meat are banned in egg-laying hens. Moreover, eggs are a complex matrix rich in protein and lipids; their lipoproteins may bind to analytes, and foam may be produced during extraction, making sample cleanup and analysis challenging.

Huertas-Perez et al. [57] used acidified acetonitrile and PSA as a sorbent for the analysis of sulfonamides in eggs by QuEChERS-HPLC-FLD. In contrast with chickens raised for meat, these antibiotics are banned in egg-laying 


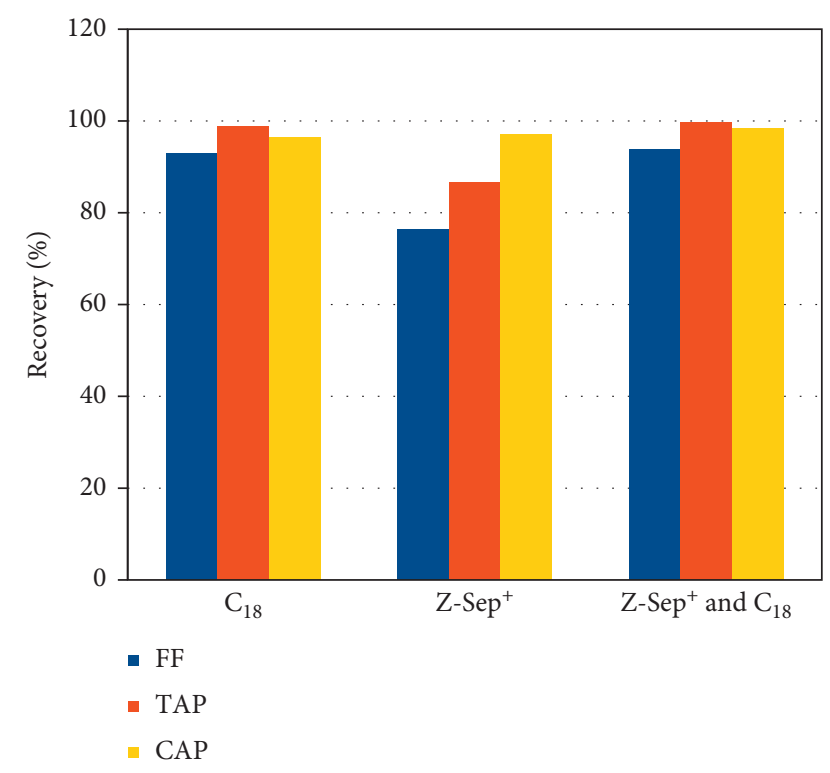

FIGURE 4: Effect of sorbent on the recoveries of florfenicol (FF), thiamphenicol (TAP), and chloramphenicol (CAP) from milk samples extracted by QuEChERS, according to data in [21]. Sorbents were $\mathrm{C}_{18}(350 \mathrm{mg}), \mathrm{Z}_{-} \mathrm{Sep}^{+}(500 \mathrm{mg})$, and Z-Sep ${ }^{+}$(500 mg) combined with $\mathrm{C}_{18}(350 \mathrm{mg})$.

hens. Postcolumn photochemical derivatization was performed to increase the sensitivity of the method, achieving LODs $<9 \mu \mathrm{g} / \mathrm{kg}$, except in the case of sulfachloropyridazine. Acidified acetonitrile was also used to improve the extraction of polar pesticides in eggs, and clean samples were attained using a commercial sorbent (Bond Elut d-SPE universal kit) [32]; the method yielded good recoveries (70\%-108\%) and low LOQs of $0.3-6 \mathrm{ng} / \mathrm{g}$, which are well below the MRLs $(\geq 50 \mathrm{ng} / \mathrm{g})$ of the pesticides analyzed.

Melamine is a nitrogenated compound used in the manufacture of plastics and has been illegally added to milk to increase its protein content, with nefarious effects on human health as melamine exhibits renal toxicity. Melamine can also be generated as a by-product of the metabolism of cyromazine in hens. Cyromazine is an insecticide added to the feed of egg-laying hens to prevent maggot infestations in their manure; however, residues of both the insecticide and its melamine metabolite require careful monitoring because of their toxicity. Melamine and cyromazine have been extracted using QuEChERS with acidified acetonitrile or a methanol-acetonitrile mixture and determined by HPLC-DAD [29] or LC-MS/MS [30]. Between these two methods, the recoveries $(83 \%-105 \%)$ obtained by the method of Wang et al. [30] were slightly higher, but the LOQ obtained by Tsartsali and Samanidou [29] was substantially lower ( 2.5 versus $8 \mu \mathrm{g} / \mathrm{kg}$ ); thus, considering the performance of the methods and cost of the equipment, QuEChERS-HPLC-DAD is a valid option for determining melamine in eggs. In this report [29], using a combination of methanol and acetonitrile yielded substantially higher recoveries than those obtained with other solvents (Figure 5), demonstrating that solvent selection is crucial for a successful QuEChERS extraction.

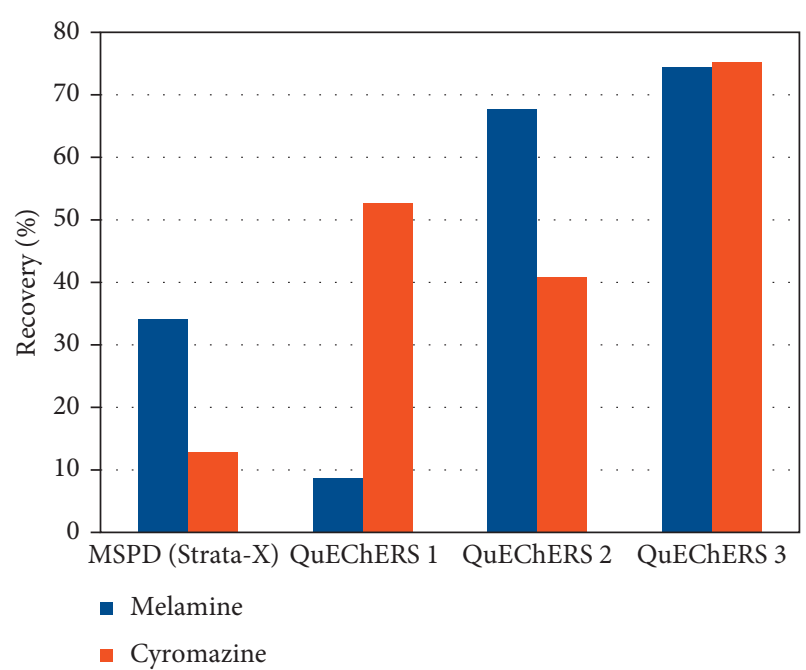

FIGURE 5: Effects of solvent on the recoveries of melamine and cyromazine from eggs, using a commercial QuEChERS sorbent for fatty samples (QuEChERS $1=2 \mathrm{~mL} \mathrm{MeCN}$, QuEChERS $2=2 \mathrm{~mL}$ $\mathrm{MeOH}$, and QuEChERS $3=1 \mathrm{~mL} \mathrm{MeOH}+1 \mathrm{~mL} \mathrm{MeCN})$ and comparison with matrix solid-phase dispersion (MSPD), according to data in [29].

Mycotoxins can contaminate eggs when hens ingest contaminated feed. Because mycotoxins are powerful carcinogens, their presence in food products should be carefully monitored. Mycotoxins have been determined in eggs using QuEChERS-UPLC-MS/MS either with a cleanup step [28] or without it [31]. The method of Li et al. [28] achieved slightly higher recoveries $(85 \%-115 \%)$, but that of Frenich et al. [31] achieved lower LOQs $(1-2 \mu \mathrm{g} / \mathrm{kg}$ versus $3-15 \mu \mathrm{g} / \mathrm{kg}$ ) for aflatoxins and faster separation. Nevertheless, both proved to be applicable to real samples, detecting residues of aflatoxins in at least one egg sample.

2.5. Fish. The contamination of aqueous ecosystems with pesticides, pharmaceutical waste, heavy metals, and other substances has resulted in the accumulation of xenobiotics in fish, representing a risk to human health. Therefore, effective multiresidue analysis methods are necessary to monitor the presence of these contaminants in fish. Because of their speed, robustness, and environmental friendliness, QuEChERS-based methods have been used to analyze various contaminants in fish, with excellent results.

The most important contaminants in fish are persistent organic pollutants such as organochlorine pesticides and polychlorinated biphenyls, which accumulate in the adipose tissue and have negative effects on human health. A modified QuEChERS method using $\mathrm{CaCl}_{2}$ and PSA and a freezing-out step for removing fats from fish tissue attained good GC-MS recoveries $(70 \%-115 \%)$ for both organochlorine pesticides and polychlorinated biphenyls in tilapia, although recoveries in salmon were lower likely because of the high fat content of this fish [34]. Nevertheless, using a mixture of acetonitrile/tetrahydrofurane in this method instead of acetonitrile alone enhanced recoveries of most compounds from salmon. Another group 


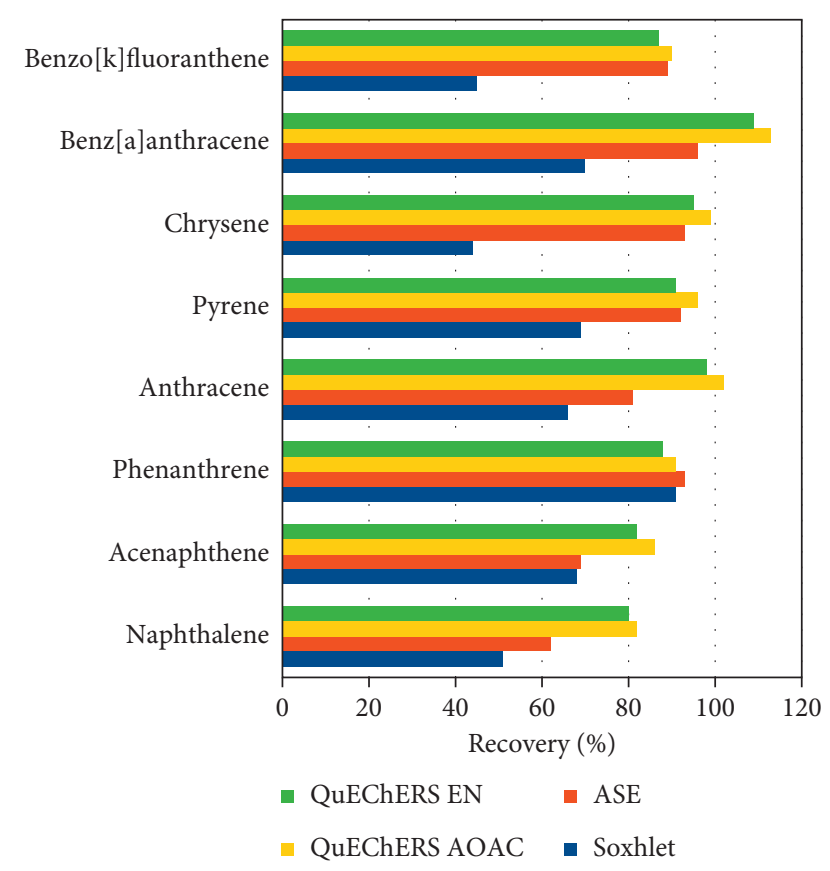

FIGURE 6: Recoveries of selected polycyclic aromatic hydrocarbons (PAHs) from fish, attained using QuEChERS with AOAC extraction salt (QuEChERS AOAC), QuEChERS with EN extraction salt (QuEChERS EN), Soxhlet with hexane, and accelerated solvent extraction (ASE) with $\mathrm{CH}_{2} \mathrm{Cl}_{2}: \operatorname{MeCN}(9: 1)$, according to data in [36].

of researchers opted for QuEChERS followed by the DLLME-SFO technique for cleanup of tilapia samples for determining organochlorine pesticides by GC-ECD, achieving recoveries $>88 \%$ [41].

Polycyclic aromatic hydrocarbons (PAHs) are another group of important contaminants in fish. PAHs are combustion by-products that can accumulate in the adipose tissue and exhibit mutagenic and carcinogenic effects. QuEChERS-GC/MS has been successfully used to determine PAHs in fatty fish including herring and salmon $[35,36]$. Forsberg et al. [36] used ethyl acetate, acetone, and isooctane instead of the more common acetonitrile for the QuEChERS extraction and attained overall recoveries almost $40 \%$ higher than those achieved by the traditional Soxhlet method. A comparison of the recoveries of selected PAHs obtained with QuEChERS and other methods as reported by [36] is shown in Figure 6. Moreover, like in meat, QuEChERS proved useful for determining PCBs in fish, also attaining low LOQs (<1 ng/g) [39].

Veterinary drugs are used in fish farming because of the intensity of such operations, in which large numbers of fish are raised in a small space, becoming prone to infection by microorganisms and parasites. QuEChERS has been applied for the determination of malachite green [59] and quinolones [40] in fish, using LC-MS/MS and UPLC-FLD, respectively.

For multiclass pesticide analysis in fish muscle, a novel dual d-SPE cleanup step was introduced [38]. Briefly, after partition of the extract with salts, a first cleanup was performed using PSA, SAX, $\mathrm{NH}_{2}$, and $\mathrm{MgSO}_{4}$, and the obtained supernatant was subjected to a second cleanup with $C_{18}$ followed by freezing-out. As a result, cleaner samples and increased sensitivity was attained, with GC-MS recoveries of $70 \%-120 \%$ and LOQs in the range $0.004-0.009 \mathrm{mg} / \mathrm{kg}$. In addition, multiclass analysis of pharmaceuticals in bivalves attained LOQs $<100 \mathrm{ng} / \mathrm{g}$ and revealed the presence of salicylic acid, demonstrating that metabolites of pharmaceuticals can contaminate aquatic species [42].

In addition to contaminants derived from human activities, paralytic shellfish poisoning toxins, which are produced by algae and cause severe food poisoning, have also been determined using QuEChERS [43].

2.6. Honey. Honey is a complex mixture of sugars and waxes that vary according to the nectar used by the bees to create it, making its analysis challenging. Pesticide contamination of nectar and honey is not only of concern to human health but also may be associated with the phenomenon of disappearance of hives. Therefore, monitoring of pesticide residues in honey is of interest to ensure its safety to consumers and to determine if pesticides are being accumulated and affect beehives. A multiresidue QuEChERS-based method for analyzing pesticides in honey was proposed [45]; the honey was heated and dissolved in $\mathrm{Na}_{2}$ EDTA prior to extraction with acetonitrile and d-SPE, and the resulting extract was analyzed by GC-ECD. Another method used UPLC-MS/MS for determining pesticides after QuEChERS extraction, which involved dissolving the honey in water and using a mixture of acidified acetonitrile/ethyl acetate [46]. The method of Tette et al. [46] did not require heating the honey samples and achieved a faster separation than that of Orso et al. [45], although the LODs were comparable.

Among pesticides, neonicotinoids are of particular concern because of their harmful effects on bees and their possible role in bee colony collapse. QuEChERS extraction of neonicotinoids from honey was achieved by dissolving honey samples in water and extracting them with acetonitrile, using SPE citrate sorbent for d-SPE; the clean extracts were then analyzed by UPLC-MS/MS, achieving LODs $<2.5 \mu \mathrm{g} / \mathrm{kg}[60]$.

The presence of antibiotic residues in honey is also of concern. For analyzing nitrofurans and nitroimidazoles in honey, samples were derivatized with acid, QuEChERS extraction was performed without sorbent addition, and the extract was evaporated and reconstituted prior to LCMS/MS analysis; the validated method complied with European guidelines [44].

Because honey can also be simultaneously contaminated with various xenobiotics, a multiresidue method able to determine various compound classes would be useful; such a method was recently reported, using a combination of conventional QuEChERS and SPME with both LC-MS/MS and GC-MS/MS for determining more than 100 compounds between pesticides, PAHs, and PCBs [47].

In addition to contaminants derived from human activities, it is known that honey may become contaminated with natural toxins like alkaloids from various plant species, which is of concern particularly when children consume it; 
thus, QuEChERS was recently applied to determine both pyrrolizidine and tropane alkaloids in honey [48].

\section{Final Considerations}

The QuEChERS methodology has been successfully applied for the analysis of various contaminants in food products of animal origin, yielding high recoveries that are comparably higher than those obtained with other techniques, while decreasing the needs for time and reagents. Nevertheless, to ensure the success of this technique, solvent and sorbent selection is of critical importance. As shown in Table 1, acetonitrile has been the solvent of choice for QuEChERS extractions because it can be easily separated from water by salt partitioning, tends to extract less interfering substances compared with other solvents, and the produced extract can be analyzed by gas or liquid chromatography [2]. Acetonitrile has been used alone, mixed with water, or modified by adding acids. Although sample : solvent ratios vary, ratios of 1:2 are common. Greater solvent volumes tend to yield higher recoveries, up to a certain point $[23,55]$; thus, the volume used also has to be optimized. Acetonitrile added with acetic acid was found to improve the extraction of ractopamine in pork [16] and antibiotics and antiviral compounds in chicken $[4,19]$, whereas acetonitrile acidified with formic acid was used for extracting quinolones from fish [40]. High-fat samples have been extracted with other solvents such as hexane and acetone followed by acetonitrile extraction, or a combination of solvents capable of dissolving fat like the acetone/ethyl acetate/isooctane mixture used to extract PAHs from salmon [36]. Partitioning is achieved using $\mathrm{NaCl}$ and $\mathrm{MgSO}_{4}$ in most cases, although buffered salts have been used for extracting contaminants such as nitrites from bacon [13], veterinary drugs from chicken [20], steroids from milk [26], and PAHs from salmon [36]. Subsequently, the extracts are cleaned up by d-SPE, for which the sorbents must be chosen depending on the characteristics of the matrix and compounds of interest. $\mathrm{MgSO}_{4}$ and PSA are common sorbents used for various contaminants and matrices, whereas $\mathrm{C}_{18}$ is added for the cleanup of high-fat samples including milk, bacon, red meats, eggs, and fish. Novel sorbents such as Z-Sep and Z-Sep ${ }^{+}$, which are a combination of $\mathrm{C}_{18}$ and $\mathrm{ZrO}_{2}$, have been used in combination with $\mathrm{C}_{18}$ and PSA to improve the cleanup of high-fat samples such as bacon and milk $[13,21,25]$, and they have been promoted as a convenient replacement for the traditional PSA $+\mathrm{C}_{18}$ combination used for such samples. Fat removal can also be achieved by freezing-out of samples, although to obtain cleaner extracts, this step is preceded by d-SPE as described above. To overcome the disadvantage of producing extracts with low concentrations of compounds, evaporating and redissolving the sample in a small amount of solvents is commonly done. One of the problems reported for QuEChERS extracts of lipophilic compounds such as organochlorine pesticides is their low enrichment factor; thus, QuEChERS has been combined with the DLLME-SFO technique to produce cleaner and more concentrated extracts yielding higher recoveries, an example being a report on the analysis of organochlorine pesticides in fish samples [41]. Nanotechnology has also appeared in the development of QuEChERS methods, with a report describing the use of $\mathrm{ZnO}$ nanoparticles and PSA for purifying milk and honey extracts containing steroids [22]. However, this d-SPE step has been omitted in some reports without negative effects, including the analysis of mycotoxins in eggs [31] and nitrofuran metabolites in honey [44], which may be due to the limited number of target compounds in these cases.

\section{Conclusion}

The QuEChERS methodology has demonstrated to be applicable to the analysis of various xenobiotics including pesticides, hormones, toxins, and antibiotics in animal matrices such as meat, milk, eggs, and honey. QuEChERS exhibits advantages over traditional methods because of its speed, efficiency, and environmental friendliness. Recoveries obtained using QuEChERS tend to be comparable or even higher than those obtained by solvent extraction or SPE, while reducing the need for solvent as well as the analysis time. QuEChERS has also proven to be applicable to the analysis of compounds that are of particular concern in recent times, such as melamine and ractopamine. Therefore, it is expected that new modifications to the QuEChERS methodology will continue to be developed to facilitate the analysis of more veterinary drugs and other xenobiotics in animal products, and the methodology may become a favored choice for the monitoring of these substances in the future.

\section{Conflicts of Interest}

The authors declare no conflicts of interest.

\section{Acknowledgments}

This research was supported by the Bisa Research Grant of Keimyung University in 2015.

\section{References}

[1] M. Anastassiades, S. J. Lehotay, D. Tajnbaher, and F. J. Schenck, "Fast and easy multiresidue method employing acetonitrile extraction/partitioning and "dispersive solidphase extraction" for the determination of pesticide residues in produce," Journal of AOAC International, vol. 86, no. 2, pp. 412-431, 2003.

[2] A. Wilkowska and M. Biziuk, "Determination of pesticide residues in food matrices using the QuEChERS methodology," Food Chemistry, vol. 125, no. 3, pp. 803-812, 2011.

[3] R. Pérez-Burgos, E. M. Grzelak, G. Gokce, J. Saurina, J. Barbosa, and D. Barrón, "QuEChERS methodologies as an alternative to solid phase extraction (SPE) for the determination and characterization of residues of cephalosporins in beef muscle using LC-MS/MS," Journal of Chromatography B, vol. 899, pp. 57-65, 2012.

[4] S. C. Machado, M. Landin-Silva, P. P. Maia, S. Rath, and I. Martins, "QuEChERS-HPLC-DAD method for sulphonamides in chicken breast," Brazilian Journal of Pharmaceutical Sciences, vol. 49, no. 1, pp. 155-166, 2013. 
[5] X.-X. Miao, D.-B. Liu, Y.-R. Wang, Y.-Y. Yang, X.-Y. Yang, and H.-R. Gong, "Modified QuEChERS in combination with dispersive liquid-liquid microextraction based on solidification of the floating organic droplet method for the determination of organophosphorus pesticides in milk samples," Journal of Chromatographic Science, vol. 53, no. 10, pp. 1813-1820, 2015.

[6] K. Mastovska, K. J. Dorweiler, S. J. Lehotay, J. S. Wegscheid, and K. A. Szpylka, "Pesticide multiresidue analysis in cereal grains using modified QuEChERS method combined with automated direct sample introduction GC-TOFMS and UPLC-MS/MS techniques," Journal of Agricultural and Food Chemistry, vol. 58, no. 10, pp. 5959-5972, 2010.

[7] U. Koesukwiwat, S. J. Lehotay, K. Mastovska, K. J. Dorweiler, and N. Leepipatpiboon, "Extension of the QuEChERS method for pesticide residues in cereals to flaxseeds, peanuts, and doughs," Journal of Agricultural and Food Chemistry, vol. 58, no. 10, pp. 5950-5958, 2010.

[8] K. Mastovska and S. J. Lehotay, "Rapid sample preparation method for LC-MS/MS or GC-MS analysis of acrylamide in various food matrices," Journal of Agricultural and Food Chemistry, vol. 54, no. 19, pp. 7001-7008, 2006.

[9] A. Y. Sirhan, G. H. Tan, and R. C. S. Wong, "Method validation in the determination of aflatoxins in noodle samples using the QuEChERS method (quick, easy, cheap, effective, rugged and safe) and high performance liquid chromatography coupled to a fluorescence detector (HPLC-FLD)," Food Control, vol. 22, no. 12, pp. 1807-1813, 2011.

[10] K. Lichtmannegger, R. Fischer, F. X. Steemann, H. Unterluggauer, and S. Masselter, "Alternative QuEChERSbased modular approach for pesticide residue analysis in food of animal origin," Analytical and Bioanalytical Chemistry, vol. 407, no. 13, pp. 3727-3742, 2015.

[11] B. Kinsella, P. Byrne, H. Cantwell, M. McCormack, A. Furey, and M. Danaher, "Determination of the new anthelmintic monepantel and its sulfone metabolite in milk and muscle using a UHPLC-MS/MS and QuEChERS method," Journal of Chromatography B, vol. 879, no. 31, pp. 3707-3713, 2011.

[12] N. C. Sartarelli, A. N. de Macedo, J. P. de Sousa, A. R. D. A. Nogueira, and S. H. G. Brondi, "Determination of chlorfenvinphos, fipronil, and cypermethrin residues in meat and bovine fat using QuEChERS method and gas chromatography-mass spectrometry," Journal of Liquid Chromatography \& Related Technologies, vol. 35, no. 13, pp. 1895-1908, 2012.

[13] S. J. Lehotay, Y. Sapozhnikova, L. Han, and J. J. Johnston, "Analysis of nitrosamines in cooked bacon by QuEChERS sample preparation and gas chromatography-tandem mass spectrometry with backflushing," Journal of Agricultural and Food Chemistry, vol. 63, no. 47, pp. 10341-10351, 2015.

[14] O. Kuzukiran and A. Filazi, "Determination of selected polychlorinated biphenyl residues in meat products by QuEChERS method coupled with gas chromatography-mass spectrometry," Food Analytical Methods, vol. 9, no. 7, pp. 1867-1875, 2016.

[15] M. Paramasivam, R. Harischandra Naik, and S. Chandrasekaran, "QuEChERS method for determination of some chlorinated hydrocarbon and synthetic pyrethroid residues in sheep meat by gas chromatography-electron capture detector," Madras Agricultural Journal, vol. 98, no. 7-9, pp. 282-285, 2011.

[16] A. C. Valese, G. A. P. Oliveira, C. R. Kleemann, L. Molognoni, and H. Daguer, "A QuEChERS/LC-MS method for the analysis of ractopamine in pork," Journal of Food Composition and Analysis, vol. 47, pp. 38-44, 2016.
[17] X. Xu, X. Zhang, E. Duhoranimana, Y. Zhang, and P. Shu, "Determination of methenamine residues in edible animal tissues by HPLC-MS/MS using a modified QuEChERS method: validation and pilot survey in actual samples," Food Control, vol. 61, pp. 99-104, 2016.

[18] H. Yan, X. Liu, F. Cui et al., "Determination of amantadine and rimantadine in chicken muscle by QuEChERS pretreatment method and UHPLC coupled with LTQ Orbitrap mass spectrometry," Journal of Chromatography B, vol. 938, pp. 8-13, 2013.

[19] P. Mu, N. Xu, T. Chai et al., "Simultaneous determination of 14 antiviral drugs and relevant metabolites in chicken muscle by UPLC-MS/MS after QuEChERS preparation," Journal of Chromatography B, vol. 1023-1024, pp. 17-23, 2016.

[20] R. P. Lopes, R. C. Reyes, R. Romero-González, A. G. Frenich, and J. L. M. Vidal, "Development and validation of a multiclass method for the determination of veterinary drug residues in chicken by ultra high performance liquid chromatography-tandem mass spectrometry," Talanta, vol. 89, pp. 201-208, 2012.

[21] H.-Y. Liu, S.-L. Lin, and M.-R. Fuh, "Determination of chloramphenicol, thiamphenicol and florfenicol in milk and honey using modified QuEChERS extraction coupled with polymeric monolith-based capillary liquid chromatography tandem mass spectrometry," Talanta, vol. 150, pp. 233-239, 2016.

[22] H. Liu, T. Lin, X. Cheng, N. Li, L. Wang, and Q. Li, "Simultaneous determination of anabolic steroids and $\beta$-agonists in milk by QuEChERS and ultra high performance liquid chromatography tandem mass spectrometry," Journal of Chromatography B, vol. 1043, pp. 176-186, 2017.

[23] N. Li, L. Lei, L. Nian et al., "A modified QuEChERS method for the determination of some herbicides in yogurt and milk by high performance liquid chromatography," Talanta, vol. 105, pp. 219-228, 2013.

[24] I.-S. Jeong, B.-M. Kwak, J.-H. Ahn, and S.-H. Jeong, "Determination of pesticide residues in milk using a QuEChERSbased method developed by response surface methodology," Food Chemistry, vol. 133, no. 2, pp. 473-481, 2012.

[25] T. Rejczak and T. Tuzimski, "QuEChERS-based extraction with dispersive solid phase extraction clean-up using PSA and $\mathrm{ZrO}_{2}$-based sorbents for determination of pesticides in bovine milk samples by HPLC-DAD," Food Chemistry, vol. 217, pp. 225-233, 2017.

[26] X.-T. Tan, Z.-M. Li, L.-G. Deng, S.-C. Zhao, and M.-L. Wang, "Analysis of 13 kinds of steroid hormones in raw milk using modified QuEChERS method combined with UPLC-QTOFMS," Journal of Integrative Agriculture, vol. 15, no. 9, pp. 2163-2174, 2016.

[27] S. R. Parab and P. N. Amritkar, "Development and validation of a procedure for determination of sulfonamide residues in pasteurized milk using modified QuEChERS method and liquid chromatography/tandem mass spectrometry," Journal of AOAC International, vol. 95, no. 5, pp. 1528-1533, 2012.

[28] Y. Li, S. Wen, Z. Chen, Z. Xiao, and M. Ma, "Ultra-high performance liquid chromatography tandem mass spectrometry for simultaneous analysis of aflatoxins B1, G1, B2, G2, zearalenone and its metabolites in eggs using a QuEChERS-based extraction procedure," Analytical Methods, vol. 7, no. 10, pp. 4145-4151, 2015.

[29] N. Tsartsali and V. F. Samanidou, "Sample preparation of eggs from laying hens using QuEChERS dispersive extraction for the simultaneous determination of melamine and cyromazine 
residues by HPLC-DAD," Analytical Chemistry Insights, vol. 10, pp. 53-58, 2015.

[30] P.-C. Wang, R.-J. Lee, C.-Y. Chen, C.-C. Chou, and M.-R. Lee, "Determination of cyromazine and melamine in chicken eggs using quick, easy, cheap, effective, rugged and safe (QuEChERS) extraction coupled with liquid chromatography-tandem mass spectrometry," Analytica Chimica Acta, vol. 752, pp. 78-86, 2012.

[31] A. G. Frenich, R. Romero-González, M. L. Gómez-Pérez, and J. L. M. Vidal, "Multi-mycotoxin analysis in eggs using a QuEChERS-based extraction procedure and ultra-highpressure liquid chromatography coupled to triple quadrupole mass spectrometry," Journal of Chromatography A, vol. 1218, no. 28, pp. 4349-4356, 2011.

[32] S. Choi, S. Kim, J. Y. Shin, M. Kim, and J.-H. Kim, "Development and verification for analysis of pesticides in eggs and egg products using QuEChERS and LC-MS/MS," Food Chemistry, vol. 173, pp. 1236-1242, 2015.

[33] M. M. Rahman, S.-W. Kim, T. W. Na et al., "QuEChERS method for the simultaneous quantification of phorate and its metabolites in porcine and chicken muscle and table eggs using ultra-high performance liquid chromatography with tandem mass spectrometry," Journal of Separation Science, vol. 39, no. 11, pp. 2079-2086, 2016.

[34] H. R. Norli, A. Christiansen, and E. Deribe, "Application of QuEChERS method for extraction of selected persistent organic pollutants in fish tissue and analysis by gas chromatography mass spectrometry," Journal of Chromatography A, vol. 1218, no. 41, pp. 7234-7241, 2011.

[35] M. Khorshid, E. R. Souaya, A. H. Hamzawy, and M. N. Mohammed, "QuEChERS method followed by solid phase extraction method for gas chromatographic-mass spectrometric determination of polycyclic aromatic hydrocarbons in fish," International Journal of Analytical Chemistry, vol. 2015, Article ID 352610, 7 pages, 2015.

[36] N. D. Forsberg, G. R. Wilson, and K. A. Anderson, "Determination of parent and substituted polycyclic aromatic hydrocarbons in high-fat salmon using a modified QuEChERS extraction, dispersive SPE and GC-MS," Journal of Agricultural and Food Chemistry, vol. 59, no. 15, pp. 8108-8116, 2011.

[37] L. Yao, J.-L. Zhao, Y.-S. Liu, Y.-Y. Yang, W.-R. Liu, and G.-G. Ying, "Simultaneous determination of 24 personal care products in fish muscle and liver tissues using QuEChERS extraction coupled with ultra pressure liquid chromatographytandem mass spectrometry and gas chromatography-mass spectrometer analyses," Analytical and Bioanalytical Chemistry, vol. 408, no. 28, pp. 8177-8193, 2016.

[38] J. M. Molina-Ruiz, E. Cieslik, I. Cieslik, and I. Walkowska, "Determination of pesticide residues in fish tissues by modified QuEChERS method and dual-d-SPE clean-up coupled to gas chromatography-mass spectrometry," Environmental Science and Pollution Research, vol. 22, no. 1, pp. 369-378, 2015.

[39] N. Chamkasem, S. Lee, and T. Harmon, "Analysis of 19 PCB congeners in catfish tissue using a modified QuEChERS method with GC-MS/MS," Food Chemistry, vol. 192, pp. 900-906, 2016.

[40] M. Lombardo-Agüí, A. M. García-Campaña, C. CrucesBlanco, and L. Gámiz-Gracia, "Determination of quinolones in fish by ultra-high performance liquid chromatography with fluorescence detection using QuEChERS as sample treatment," Food Control, vol. 50, pp. 864-868, 2015.

[41] X.-C. Wang, B. Shu, S. Li, Z.-G. Yang, and B. Qiu, "QuEChERS followed by dispersive liquid-liquid microextraction based on solidification of floating organic droplet method for organochlorine pesticides analysis in fish," Talanta, vol. 162, pp. 90-97, 2017.

[42] M. Núñez, F. Borrull, N. Fontanals, and E. Pocurull, "Determination of pharmaceuticals in bivalves using QuEChERS extraction and liquid chromatography-tandem mass spectrometry," Analytical and Bioanalytical Chemistry, vol. 407, no. 13, pp. 3841-3849, 2015.

[43] M. Mattarozzi, M. Milioli, F. Bianchi et al., "Optimization of a rapid QuEChERS sample treatment method for HILIC-MS ${ }^{2}$ analysis of paralytic shellfish poisoning (PSP) toxins in mussels," Food Control, vol. 60, pp. 138-145, 2016.

[44] A. H. Shendy, M. A. Al-Ghobashy, S. A. Gad Alla, and H. M. Lotfy, "Development and validation of a modified QuEChERS protocol coupled to LC-MS/MS for simultaneous determination of multi-class antibiotic residues in honey," Food Chemistry, vol. 190, pp. 982-989, 2016.

[45] D. Orso, M. L. Martins, F. F. Donato et al., "Multiresidue determination of pesticide residues in honey by modified QuEChERS method and gas chromatography with electron capture detection," Journal of the Brazilian Chemical Society, vol. 25, pp. 1355-1365, 2014.

[46] P. A. S. Tette, F. A. da Silva Oliveira, E. N. C. Pereira, G. Silva, M. B. de Abreu Glória, and C. Fernandes, "Multiclass method for pesticides quantification in honey by means of modified QuEChERS and UHPLC-MS/MS," Food Chemistry, vol. 211, pp. 130-139, 2016.

[47] J. Al-Alam, Z. Fajloun, A. Chbani, and M. Millet, “A multiresidue method for the analysis of 90 pesticides, 16 PAHs, and 22 PCBs in honey using QuEChERS-SPME," Analytical and Bioanalytical Chemistry, vol. 409, no. 21, pp. 5157-5169, 2017.

[48] M. Martinello, A. Borin, R. Stella et al., "Development and validation of a QuEChERS method coupled to liquid chromatography and high resolution mass spectrometry to determine pyrrolizidine and tropane alkaloids in honey," Food Chemistry, vol. 234, pp. 295-302, 2017.

[49] C. K. Fagerquist, A. R. Lightfield, and S. J. Lehotay, "Confirmatory and quantitative analysis of $\beta$-lactam antibiotics in bovine kidney tissue by dispersive solid-phase extraction and liquid chromatography-tandem mass spectrometry," Analytical Chemistry, vol. 77, no. 5, pp. 1473-1482, 2005.

[50] I. F. Mitropoulos, J. C. Rotschafer, and K. A. Rodvold, "Adverse events associated with the use of oral cephalosporins/cephems," Diagnostic Microbiology and Infectious Disease, vol. 57, no. 3, pp. S67-S76, 2007.

[51] G. Mazzanti, A. Di Sotto, C. Daniele et al., "A pharmacodynamic study on clenbuterol-induced toxicity: $\beta 1$ - and $\beta 2$ adrenoceptors involvement in guinea-pig tachycardia in an in vitro model," Food and Chemical Toxicology, vol. 45, no. 9, pp. 1694-1699, 2007.

[52] L. Wang, Y.-Q. Li, Y.-K. Zhou, and Y. Yang, "Determination of four $\beta 2$-agonists in meat, liver and kidney by GC-MS with dual internal standards," Chromatographia, vol. 71, no. 7-8, pp. 737-739, 2010.

[53] W. Du, G. Zhao, Q. Fu, M. Sun, H. Zhou, and C. Chang, "Combined microextraction by packed sorbent and highperformance liquid chromatography-ultraviolet detection for rapid analysis of ractopamine in porcine muscle and urine samples," Food Chemistry, vol. 145, pp. 789-795, 2014.

[54] G. Ding, D. Li, J. Qin et al., "Development and validation of a high-performance liquid chromatography method for determination of ractopamine residue in pork samples by solid phase extraction and pre-column derivatization," Meat Science, vol. 106, pp. 55-60, 2015. 
[55] L. Xiong, Y.-Q. Gao, W.-H. Li, X.-L. Yang, and S. P. Shimo, "Simple and sensitive monitoring of $\beta 2$-agonist residues in meat by liquid chromatography-tandem mass spectrometry using a QuEChERS with preconcentration as the sample treatment," Meat Science, vol. 105, pp. 96-107, 2015.

[56] USDA-FSIS. CLG-NTR3.01, "Analysis of nitrosamines using supercritical fluid extraction," 2009.

[57] J. F. Huertas-Pérez, N. Arroyo-Manzanares, L. Havlíková, L. Gámiz-Gracia, P. Solich, and A. M. García-Campaña, "Method optimization and validation for the determination of eight sulfonamides in chicken muscle and eggs by modified QuEChERS and liquid chromatography with fluorescence detection," Journal of Pharmaceutical and Biomedical Analysis, vol. 124, pp. 261-266, 2016.

[58] A. V. Sartori, J. Swensson de Mattos, M. H. P. de Moraes, and A. W. da Nóbrega, "Determination of aflatoxins M1, M2, B1, B2, G1, and G2 and ochratoxin A in UHT and powdered milk by modified QuEChERS method and ultra-high-performance liquid chromatography tandem mass spectrometry," Food Analytical Methods, vol. 8, no. 9, pp. 2321-2330, 2015.

[59] J. C. Hashimoto, J. A. R. Paschoal, S. C. N. Queiroz, V. L. Ferracini, M. R. Assalin, and F. G. R. Reyes, "A simple method for the determination of malachite green and leucomalachite green residues in fish by a modified QuEChERS extraction and LC/MS/MS," Journal of AOAC International, vol. 95, no. 3, pp. 913-922, 2012.

[60] M. Proietto Galeano, M. Scordino, L. Sabatino et al., "UHPLC/MS-MS analysis of six neonicotinoids in honey by modified QuEChERS: method development, validation, and uncertainty measurement," International Journal of Food Science, vol. 2013, Article ID 863904, 7 pages, 2013. 

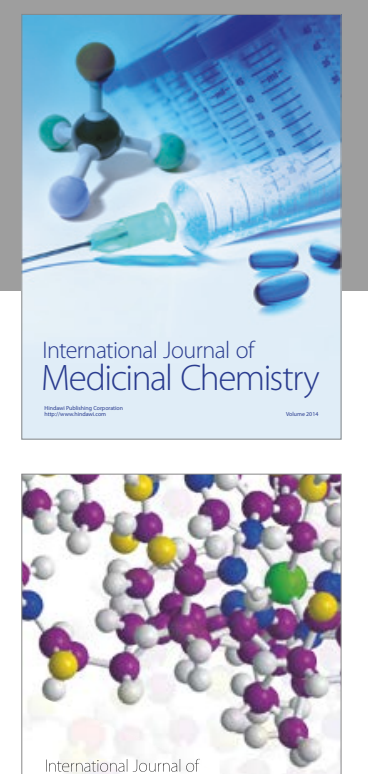

Carbohydrate Chemistry

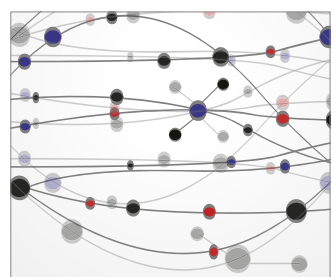

The Scientific World Journal
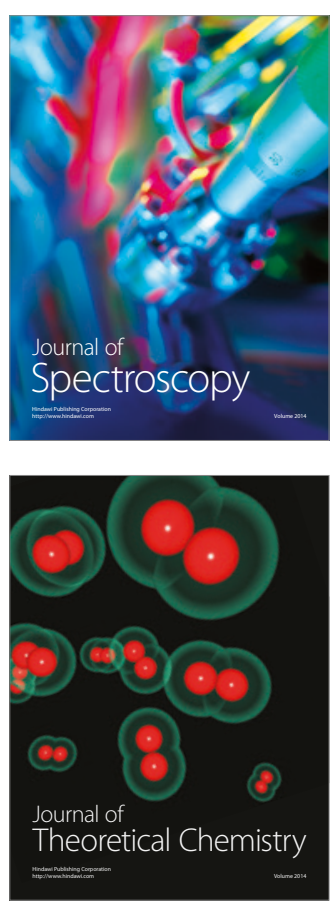
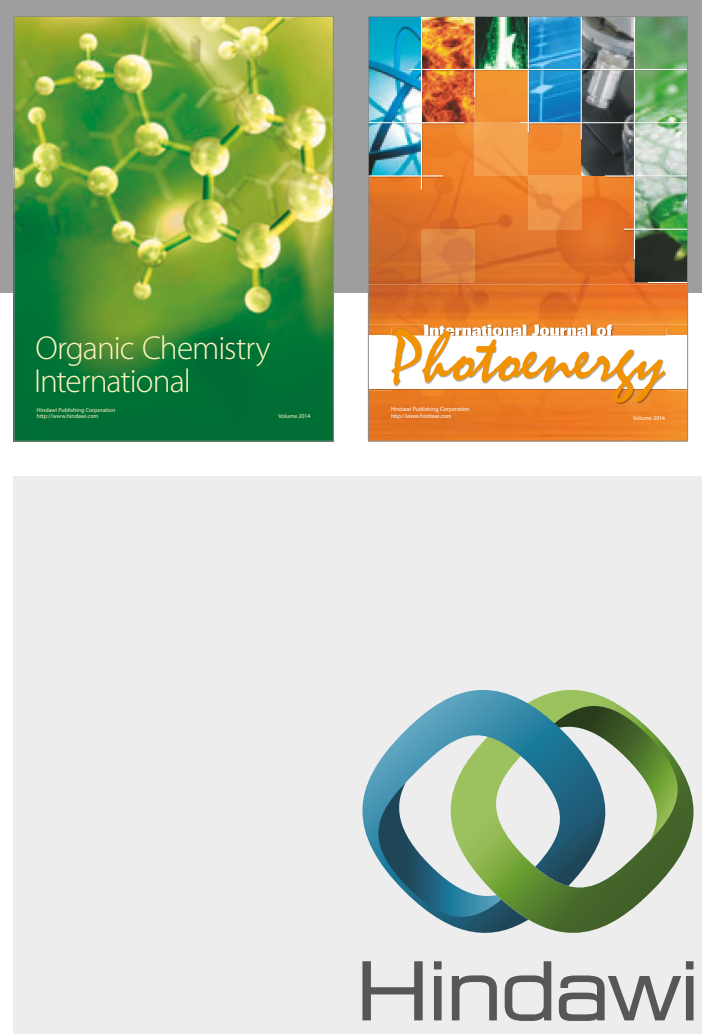

Submit your manuscripts at

https://www.hindawi.com

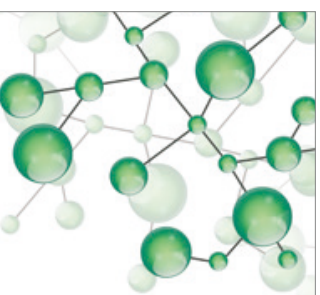

International Journal of

Inorganic Chemistry

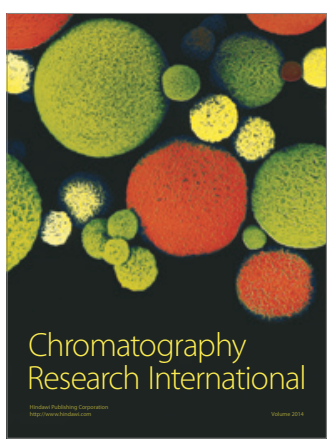

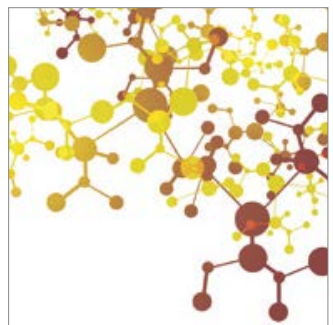

Applied Chemistry
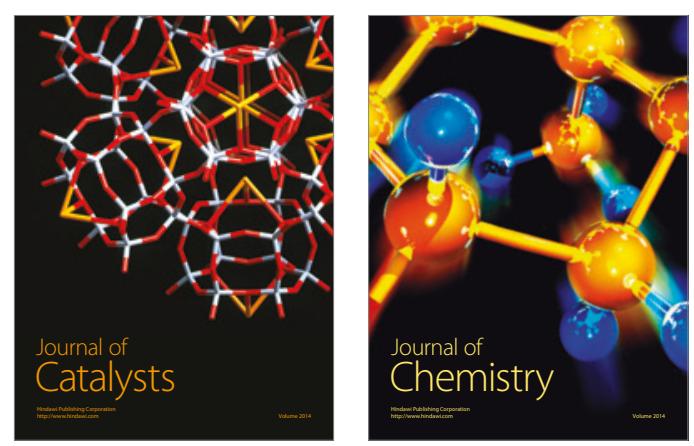
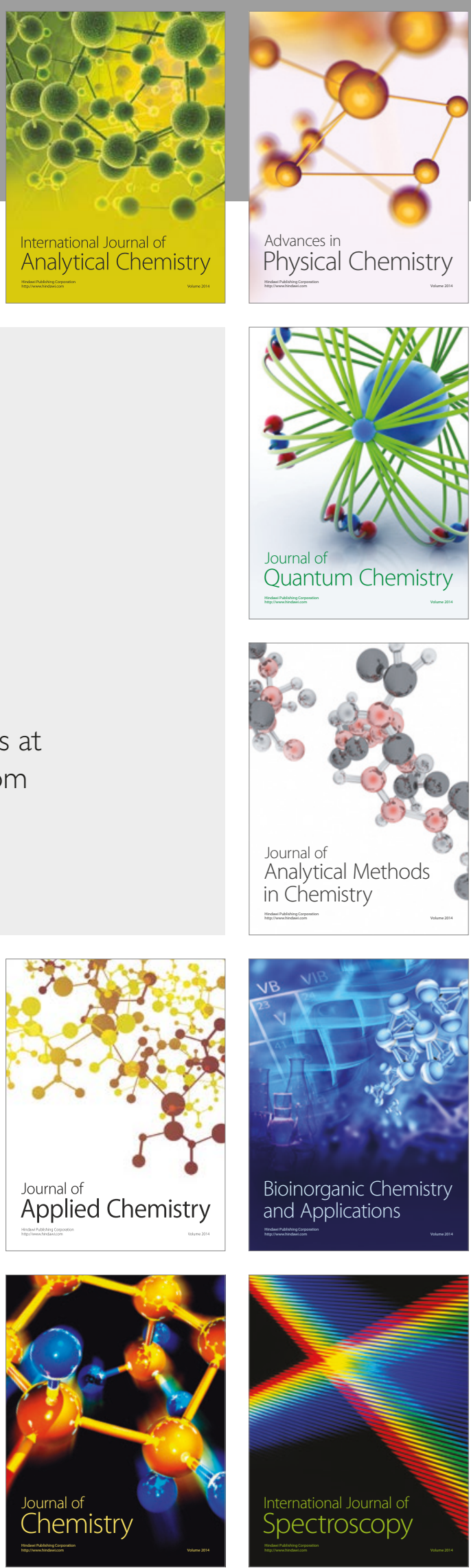